\title{
PENGARUH PEMBELAJARAN MATEMATIKA TERHADAP KEMANDIRIAN BELAJAR SISWA PADA MASA PANDEMI COVID-19 DI KELAS XI SMA NEGERI 1 KUALA
}

\author{
Rahmi Wahyuni ${ }^{1}$, Harfad $^{2}$ \\ ${ }^{1.2}$ Universitas Almuslim, Bireuen 24251, Indonesia \\ Email: rahmirusli@gmail.com \\ Email: hafadh45@gmail.com
}

\begin{abstract}
Abstrak
Tujuan penelitian ini adalah untuk mengetahui pengaruh pembelajaran matematika terhadap kemandirian belajar siswa pada masa pandemi covid-19 di kelas XI SMA Negeri 1 Kuala. Penelitian yang digunakan adalah quasi eksperimen dengan istrumen penelitian berupa lembar angket. Subjek dalam penelitian ini adalah siswa kelas XI MIA 1 dan XI MIA 3 SMA Negeri 1 Kuala dengan jumlah siswa 39 orang. Setelah diadakan penelitian data hasil angket berupa data ordinal diubah kedalam data interval dengan menggunakan method of successive interval (MSI). Hasil analisis uji normalitas sig $0.566>0.05$ (berdistribusi normal). Berdasarkan hasil uji hipotesis, diperoleh nilai sig sebesar $0,000<\alpha(0,05)$. Maka dapat disimpulkan bahwa terdapat pengaruh pembelajaran matematika terhadap kemandirian belajar siswa pada masa pandemic covid-19 di kelas XI SMA Negeri 1 Kuala. Kata kunci : Covid-19, Kemandirian Belajar Siswa, Pembelajaran Matematika
\end{abstract}

\section{Abstract}

The purpose of this study was to determine the effect of mathematics learning on student learning independence during the Covid-19 pandemic in class XI SMA Negeri 1 Kuala. The research used was a quasi-experimental research instrument in the form of a questionnaire sheet. The subjects in this study were students of class XI MIA 1 and XI MIA 3 SMA Negeri 1 Kuala with a total of 39 students. After the research was conducted, the questionnaire results in the form of ordinal data were converted into interval data using the method of successive interval (MSI). The results of the analysis of the normality test sig $0.566>0.05$ (normally distributed). Based on the results of hypothesis testing, the sig value is $0.000<(0.05)$. So it can be concluded that there is an effect of mathematics learning on the learning independence of students during the Covid-19 pandemic in class XI SMA Negeri 1 Kuala $\alpha$

Keywords: Covid-19, Self Regulated Learning(SRL), Mathematics learning

\section{PENDAHULUAN}

Saat ini kondisi dunia digemparkan dengan mewabahnya suatu penyakit yang disebabkan oleh virus yang bernama Corona atau lebih dikenal dengan Covid-19 (Corona Virus Diseases-19). Dengan adanya virus imi maka siswa terpaksa harus meakukan pembelajaran dari rumah untuk memutus tali perpanjangan penyebaran virus ini. Banyak fasilitas yang digunakan untuk pembelajaran daring, ada yang menggunakan tatap muka virtual, Learning Management System (LMS) ataupun aplikasi pada smartphone seperti grup whatsApp. Fasilitas ini menunjang supaya pembelajaran dapat terus berlangsung, namun perlu dilihat apakah pembelajaran menggunakan fasilitas tersebut dapat membuat siswa mandiri di dalam pembelajaran matematika. Siswa dapat mempelajari suatu materi ataupun mencari pengetahuan dengan metode sendiri melalui internet dan berdasarkan arahan guru. Melalui media internet siswa mampu menemukan sendiri sumber belajar dimana saja dan kapan saja siswa inginkan.

Menurut Schunk dan Zimmerman (dalam Sumarmo, 2010) mendefinisikan kemandirian belajar adalah sebagai proses belajar yang terjadi karena pengaruh dari pemikiran, perasaan, strategi dan perilaku sendiri yang berorientasi pada pencapain tujuan. Kemudian menurut Kamus Besar Bahasa Indonesia bahwa kemandirian adalah hal atau keadaan dapat berdiri sendiri tanpa bergantung pada orang lain. 
Berdasarkan hasil penelitian Wahyuni (2019) menyimpullkan bahwa mahasiswa memiliki kemandirian belajar yang tinggi dengan menggunakan pembelajaran blanded learning. Pertanyaan yang diajukan dalam bentuk pertanyaan positif. Tanggapan responden terhadap kemandirian belajar mahasiswa melalui pembelajaran blanded learning pada mata kuliah matematika ekonomi sebesar 77\% dari hasil tersebut maka tanggapan responden berada pada kriteria baik.

Selain itu, hasil penelitian dari Prayuda (2014) disimpulkan bahwa: (1) Kemandirian Belajar Siswa pada mata pelajaran ekonomi Kelas X di SMA Negeri 1 Sungai Kunyit Rendah. Hal ini ditunjukkan sebagian besar (32 siswa atau 57,14\%) siswa mendapatkan nilai antara 50 - 85,99 dengan kategori Rendah, (2) Kemandirian belajar memiliki pengaruh terhadap hasil belajar siswa kelas X di SMA Negeri 1 Sungai Kunyit. Hal ini dilihat dari nilai t hitung $>t$ tabel $(17,848>2.0049)$.

Berdasarkan hasil dari beberapa penelitian sebelumnya maka peneliti melaksanakan penelitian dengan judul pengaruh kemandirian belajar siswa terhadap pembelajaran matematika pada masa pandemi covid-19 di kelas XI SMA Negeri 1 Kuala. Penelitian ini sudah banyak dilaksanakan oleh peneliti sebelumnya, akan tetapi rata-rata penelitian yang dilakukan dengan analisis deskriptif, dimana mendeskripsikan berdasarkan hasil presentase untuk angket kemandirian belajar. Pada penelitian ini Peneliti akan menganalisis data untuk melihat pengaruh pembelajaran matematika terhapat kemandirian belajar. Untuk instrument keduanya akan menggunakan angket dengan skala liket. Hasil angket akan dianalisis dengan menggunakan regresi linear sederhana yang sebelumnya data ordinal di konvensikan ke dalam data interval.

\section{METODE PENELITIAN}

Penelitian ini menggunakan metode quasi eksperimen dengan desain penelitiannya The posttest-only control-group desain. Penelitian ini dilaksanakan pada lingkup SMAN 1 Kuala dengan subjek dalam penelitian ini adalah siswa kelas XI MIA 1 dan XI MIA 3 SMA Negeri 1 Kuala tahun ajaran 2020/2021 dengan jumlah siswa 39 orang, dalam pemilihan subjek penelitian menggunakan teknik purposive sampling. Penelitian ini dilaksanakna pada bulan September 2020. Untuk variable bebas dalam penelitian ini adalah pembelajaran matematika, sedangkan untuk variable terikat adalah kemandirian belajar.

Pengumpulan data menggunakan metode angket, dimana angketnya menggunakan skala liket dengan empat jenis respon, yaitu sangat setuju (SS), setuju (S), Tdak setuju (TS), Sangat tidak setuju (STS). Metode angket yang dipakai bertujuan untuk melihat respon siswa terhadap pembelajaran matematika dan respon siswa terhadap kemandirian belajar.

Angket respon siswa terhadap pembelajaran matematika yang terdiri dari sepuluh item pernyataan. Pernyataan tersebut menyangkut pembelajaran matematika, motivasi belajar, dan ketertarikan pada pembelajaran. Sedangkan untuk angket kemandirian belajar terdiri dari dua puluh item pernyataan. Pernyataan tersebut memuat mengenai kesadaran berfikir dalam belajar matematika, pembelajaran matematika, memotivasi dalam belajar matematika, dan keyakinan dalam belajar matematika.

Penelitian ini menggunakan instrument lembar angket. Untuk uji hipotesis menggunakan analisis statistik dengan menggunakan rumus regresi linear sederhana, namun sebelum menguji hipotesis maka dilakukan uji normalitas terlebih dahulu. Data yang dianalisis adalah data hasil angket berupa data ordinal kemudian dikonvensikan terlebih dahulu menjadi data interval dengan menggunakan method of successive interval (MSI), selanjutnya data akan diolah dengan bantuan SPSS 22.

\section{HASIL PENELITIAN DAN PEMBAHASAN}

Hasil analisis dimana data ordinal yang diperoleh dari angket pembelajaran matematika dikonvensikan ke dalam data interval menggunakan MSI. Data ordinal terlebih dahulu harus 
dikonvensi kedalam data interval supaya data tersebut dapat dianalisis menggunakan SPSS. Berikut adalah hasil konvensi data ordinal ke data interval untuk pembelajaran matematika.

Tabel 1. Hasil MSI Data Angket Pembelajaran Matematika

\begin{tabular}{|c|c|c|c|c|c|c|c|}
\hline Siswa & $\begin{array}{c}\text { Succesive } \\
\text { Interval }\end{array}$ & Siswa & $\begin{array}{c}\text { Succesive } \\
\text { Interval }\end{array}$ & Siswa & $\begin{array}{c}\text { Succesive } \\
\text { Interval }\end{array}$ & Siswa & $\begin{array}{c}\text { Succesive } \\
\text { Interval }\end{array}$ \\
\hline S1 & 42.833 & S11 & 40.119 & S21 & 31.928 & S31 & 30.710 \\
\hline S2 & 42.833 & S12 & 40.094 & S22 & 32.033 & S32 & 27.580 \\
\hline S3 & 44.132 & S13 & 41.450 & S23 & 30.862 & S33 & 26.566 \\
\hline S4 & 44.132 & S14 & 41.395 & S24 & 30.862 & S34 & 24.789 \\
\hline S5 & 44.132 & S15 & 38.636 & S25 & 29.539 & S35 & 23.037 \\
\hline S6 & 41.530 & S16 & 36.055 & S26 & 30.902 & S36 & 21.170 \\
\hline S7 & 40.153 & S17 & 36.042 & S27 & 32.073 & S37 & 20.912 \\
\hline S8 & 41.435 & S18 & 33.304 & S28 & 29.349 & S38 & 20.748 \\
\hline S9 & 40.044 & S19 & 33.304 & S29 & 33.428 & S39 & 20.390 \\
\hline S10 & 40.119 & S20 & 34.571 & S30 & 32.073 & \multicolumn{2}{|c}{} \\
\cline { 1 - 4 }
\end{tabular}

Setelah data hasil angket untuk pembelajaran matematika dikonvensikan, maka data hasil angket untuk kemandirian belajar juga harus dikonvensikan. Konvensi data tetap sama, yaitu data ordinal yang dikonvensi kedalam data interval. Data ordinal harus dirubah karena data data ordinal adalah data kualitatif atau bukan angka sebenarnya. Di dalam prosedur statistik, khususnya statistik parametrik seperti regresi linear sederhana mengharuskan data berskala interval.

Tabel 2. Hasil MSI Data Angket Kemandirian Belajar Siswa

\begin{tabular}{|c|c|c|c|c|c|c|c|}
\hline Siswa & $\begin{array}{c}\text { Succesive } \\
\text { Interval }\end{array}$ & Siswa & $\begin{array}{c}\text { Succesive } \\
\text { Interval }\end{array}$ & Siswa & $\begin{array}{c}\text { Succesive } \\
\text { Interval }\end{array}$ & Siswa & $\begin{array}{c}\text { Succesive } \\
\text { Interval }\end{array}$ \\
\hline S1 & 88.386 & S11 & 77.085 & S21 & 63.438 & S31 & 52.733 \\
\hline S2 & 85.591 & S12 & 67.272 & S22 & 60.502 & S32 & 55.669 \\
\hline S3 & 84.266 & S13 & 70.048 & S23 & 62.387 & S33 & 53.721 \\
\hline S4 & 85.418 & S14 & 64.398 & S24 & 54.511 & S34 & 52.426 \\
\hline S5 & 85.328 & S15 & 70.163 & S25 & 57.263 & S35 & 48.691 \\
\hline S6 & 82.023 & S16 & 66.180 & S26 & 54.857 & S36 & 43.457 \\
\hline S7 & 80.436 & S17 & 66.180 & S27 & 54.857 & S37 & 40.027 \\
\hline S8 & 83.350 & S18 & 58.150 & S28 & 54.136 & S38 & 34.553 \\
\hline S9 & 75.354 & S19 & 66.180 & S29 & 51.514 & S39 & 31.252 \\
\hline S10 & 76.637 & S20 & 56.739 & S30 & 55.669 & & \\
\cline { 1 - 3 }
\end{tabular}

Setelah data ordinal dikonvensi ke dalam data interval, kemudian data tersebut dianalisis untuk dilakukan penguji hipotesis. Untuk hipotesis statistik adalah sebagai berikut:

Ho : tidak terdapat pengaruh pembelajaran matematika terhadap kemandirian belajar siswa pada masa pandemi covid-19 di kelas XI SMA Negeri 1 Kuala

Ha : pengaruh pembelajaran matematika terhadap kemandirian belajar siswa pada masa pandemi covid-19 di kelas XI SMA Negeri 1 Kuala

Syarat untuk melalukan uji hipotes diantaranya adalah data harus berdistribusi normal. Maka terlebih dahulu data harus di uji normalitas, untuk melihat apakah data berdistribusi normal atau tidak. Berikut adalah hasil uji normalitas dengan menggunakan SPSS. 
One-Sample Kolmogorov-Smirnov Test

\begin{tabular}{|ll|r|}
\hline & & $\begin{array}{c}\text { Unstandardized } \\
\text { Residual }\end{array}$ \\
\hline $\mathrm{N}$ & Mean & 39 \\
Normal Parameters & $\mathrm{a}$ & .0000000 \\
& Std. Deviation & 5.18256645 \\
Most Extreme Differences & Absolute & .126 \\
& Positive & .078 \\
& Negative & -.126 \\
Kolmogorov-Smirnov Z & & .787 \\
Asymp. Sig. (2-tailed) & & .566 \\
\hline
\end{tabular}

a. Test distribution is Normal.

Berdasarkan tabel di atas maka dasar pengambilan keputusan adalah jika nilai signifikansi > 0,05 maka nilai residualnya berdistribusi normal, namun jika nilai signifikansi $<0,05$ maka nilai residual tidak berdistribusi normal. Jadi jika melihat tabel hasil analisis uji normalitas dapat disimpulkan bahwa nilai residualnya berdistribusi normal karena nilai signifikansi $0.566>0.05$

Karena data sudah berdistribusi normal, maka tahapan selanjutnya adalah melakukan uji hipotesis dengan menggunakan uji regresi linear sederhana. Analisis uji regresi linear sederhana dilakukan dengan bantuan SPSS. Berikut adalah hasil uji regresi linear sederhana dengan SPSS.

Coefficients $^{\mathrm{a}}$

\begin{tabular}{|c|c|c|c|c|c|c|}
\hline \multirow{2}{*}{\multicolumn{2}{|c|}{ Model }} & \multicolumn{2}{|c|}{ Unstandardized Coefficients } & \multirow{2}{*}{$\begin{array}{c}\begin{array}{c}\text { Standardized } \\
\text { Coefficients }\end{array} \\
\text { Beta }\end{array}$} & \multirow[b]{2}{*}{$\mathrm{t}$} & \multirow[b]{2}{*}{ Sig. } \\
\hline & & $\mathrm{B}$ & Std. Error & & & \\
\hline & (Constant) & -1.176 & 4.079 & & -.288 & .775 \\
\hline & pembelajaran matematika & 1.899 & .117 & .936 & 16.168 & .000 \\
\hline
\end{tabular}

a. Dependent Variable: kemandiran belajar

Dari tabel tersebut diperoleh nilai untuk constant (a) adalah -1.176, sedangkan nilai trust (b) adalah 1.899, sehingga persamaan regresinya dapat ditulis $\mathrm{Y}=-1.176+1.899 \mathrm{X}$. Selanjutnya di bawah ini adalah tabel untuk mengetahui nila dari $\mathrm{F}$ hitung.

\begin{tabular}{|ll|r|r|r|r|r|}
\hline \multicolumn{7}{|c|}{ ANOVA $^{\mathbf{b}}$} \\
\hline 1 & Sum of Squares & df & Mean Square & F & \multicolumn{1}{c|}{ Sig. } \\
\hline & Regression & 7211.137 & 1 & 7211.137 & 261.416 & $.000^{\mathrm{a}}$ \\
& Residual & 1020.642 & 37 & 27.585 & & \\
& Total & 8231.779 & 38 & & & \\
\end{tabular}

a. Predictors: (Constant), Pembelajaran Matematika

b. Dependent Variable: Kemandirian Belajar Siswa

Dari hasil analisis diatas diketahui bahwa nilai $\mathrm{F}$ hitung $=261.416$ dan $\mathrm{F}$ tabel 0,244 dengan demikian nilai $\mathrm{F}$ hitung 261,416 > 0,244 F tabel dan dengan tingkat signifikansi sebesar $0.000<0.05$, maka dapat di simpulkan bahwa terdapat pengaruh pembelajaran matematika terhadap kemandirian belajar siswa pada masa pandemi covid-19 di kelas XI SMA Negeri 1 Kuala. Dalam artian tolak $\mathrm{H}_{0}$ dan terima Ha. Selain itu kita juga mencari korelasi sederhana dengan bantuan SPSS. 
Correlations

\begin{tabular}{|ll|r|r|}
\hline & & $\begin{array}{c}\text { Pembelajaran } \\
\text { Matematika }\end{array}$ & $\begin{array}{c}\text { Kemandirian } \\
\text { Belajar Siswa }\end{array}$ \\
\hline Pembelajaran Matematika & Pearson Correlation & 1 & $.936^{* *}$ \\
& Sig. (2-tailed) & 39 & .000 \\
& $\mathrm{~N}$ & $.936^{* * *}$ & 39 \\
\hline Kemandirian Belajar Siswa & Pearson Correlation & .000 & 1 \\
& Sig. (2-tailed) & 39 & 39 \\
& $\mathrm{~N}$ & & \\
\hline
\end{tabular}

**. Correlation is significant at the 0.01 level (2-tailed).

Dari hasil analisis dapat disimpulkan bahwa variabel $\mathrm{X}$ terhadap variabel $\mathrm{Y}$ memiliki korelasi dengan derajad hubungan korelasi sempurna yaitu 0.936 dan bentuk hubunganya adalah postif. Adanya pengaruh pembelajaran matematika terhadap kemandirian belajar siswa pada masa pandemi covid-19 di kelas XI SMA Negeri 1 Kuala bisa disebabkan karena pembelajaran yang disajikan dengan berbagai fasilitas membuat siswa lebih mandiri dalam belajar dan mencari bahan pembelajaran.

\section{KESIMPULAN}

Berdasarkan hasil analisis data maka dapat disimpulkan bahwa :

1. Adanya pengaruh pembelajaran matematika terhadap kemandirian belajar siswa pada masa pandemi covid-19 di kelas XI SMA Negeri 1 Kuala

2. Pembelajaran matematika (X) terhadap kemandirian belajar siswa (Y) memiliki korelasi dengan derajad hubungan korelasi sempurna yaitu 0.936 dan bentuk hubunganya adalah postif.

Saran dalam penelitian ini adalah jika pembelajaran masih dilakukan secara daring ataupun online, maka buat pembelajaran bervariasi dengan menggabungkan antara tatap muka secara vitual dengan fasilitas pembelajaran online lainnya.

\section{REFERENCES}

Ahmadi \& Supriyono. (2012). Metode Research, Bandung: Alfabeta.

Anisya, Ninda. (2020). Dampak Covid-19 Indonesia Alami Krisis Pendidikan pada Anak-Anak. popmama.com/big-kid/10-12-years-old/ninda/4. Diakses pada 17 Juli 2020

Ardianto. (2019). Memahami Metode Penelitian Kualitatif. https://www.djkn.kemenkeu.go.id. Artikel. Diakses pada 10 Desember 2020

Arikunto, Suharsimi. (2006). Metode Penelitian Kualitatif. Jakarta: Bumi Aksara

Arikunto, Suharsimi. (2010). Prosedur Penelitian Suatu pendekatan Praktek. Jakarta: Rineka Cipta Gunarto. (2013). Model dan Metode Pembelajaran di Sekolah. Semarang: Unissula Press

Prayuda, Reza. (2014). Pengaruh Kemandirian Belajar Terhadap Hasil Belajar Siswa Pada Mata Pelajaran Ekonomi di SMA Negeri 1 Sungai Kunyit. Jurnal Untan. Retrieved from http://jurnal.untan.ac.id/index.php/jpdpb/article/download/6645/pdf.

Singarimbun, Masri dan Sofian Effendi. 2006. Metode Penelitian Survei (Editor). LP3ES, Jakarta.

Sumarmo, Utari.(2010). Kemandirian belajar: Apa, Mengapa, dan Bagaimana Dikembangkan Pada Peserta Didik. Retrieved from http://math.sps.upi.edu/?p=61.

Supriyanto, Helmi. (2020). Pembelajaran Daring di Masa Pandemi Covid -19. Retrieved from https://www.harianbhirawa.co.id/. 
Wahyuni, R., Nurhayati (2019). Kemandirian Belajar Mahasiswa melalui Blended Learning pada Mata Kuliah Matematika Ekonomi. Jurnal Ilmiah Pendidikan Matematika Al Qalasadi, 3(2), 76-81 . https://doi.org/10.32505/qalasadi.v3i2.1365 